\title{
Chemical Constituents from Luxemburgia nobilis (EICHL)
}

\author{
Mário G. de Carvalho ${ }^{a *}$, Márcia C. C. de Oliveira a and Alceni A. Werle \\ ${ }^{a}$ Departamento de Química - ICE, Universidade Federal Rural do Rio de Janeiro, 23851-970, Seropédica - RJ, Brazil. \\ ${ }^{\mathrm{b}}$ Departamento de Química - ICEB, Universidade Federal de Ouro Preto, Ouro Preto - MG, Brazil.
}

\begin{abstract}
O fracionamento cromatográfico do extrato hexânico dos galhos de Luxemburgia nobilis (Ochnaceae) forneceu $\beta$-sitosterol, estigmasterol, ácido betulínico, os ácidos graxos hexadecanóico, tetraeicosanóico, hexaeicosanóico e linoleico, 14-metilpentadecanoato de metila, óxido de 13epimanoíla, o depsídeo atranorina (1), e dois triglicerídeos novos (23). As estruturas das substâncias isoladas foram determinadas através da análise dos dados espectroscópicos de I.V., massas e RMN de ${ }^{1} \mathrm{H}$ e de ${ }^{13} \mathrm{C}$ incluindo comparação com dados da literatura. A análise do espectro de massas (FAB-MS) dos éteres tiometílicos ( $\mathbf{4}$ e 5) foi usada para definir as estruturas dos triglicerídeos.
\end{abstract}

Chromatographic fractionation of the hexane extract from the branches of Luxemburgia nobilis (Ochnaceae) afforded $\beta$-sitosterol, stigmasterol, betulinic acid, linoleic acid, methyl-14methylpentadecanoate, 13-epimanoyl oxide, hexadecanoic acid, tetraeicosanoic acid, hexaeicosanoic acid, the depside atranorin (1) and two new triglycerides ( $\mathbf{2}$ and $\mathbf{3}$ ). The structures were defined by IR, MS and ${ }^{1} \mathrm{H}$ - and ${ }^{13} \mathrm{C}-\mathrm{NMR}$ spectral analysis involving comparison with literature data. The FAB-MS spectra analysis of the thiomethyl ethers ( 4 and $\mathbf{5})$ were used to define the structures of the triglycerides.

Keyword: Luxemburgia nobilis, Ochnaceae, triglycerides

\section{Introduction}

In the course of our Brazilian plants phytochemical and pharmacological investigations we decided to study species of the Ochnaceae. This family contains species that have been used as medicinal plants ${ }^{1,2}$. We have previously reported the presence of triterpenes, a biflavone, biisoflavanones and an isoflavone in Ouratea hexasperma ${ }^{3,4}$. In recent publications we described the occurence of biflavones, flavonoid glycosides, chloroisoflavonoids, norisoprenoids, diterpenes, lignans, triterpenes and steroids in $O$. semisserata ${ }^{5-7}$. In these studies we have also detected the growth inhibition of murine tumour and antiproliferative effects, as well as activation of apoptosis on Ehrlich tumour cells, by biflavones isolated from these species 8 .

In this first phytochemical analysis of Luxemburgia genus (Ochnaceae) we report the presence of the known compounds $\beta$-sitosterol, stigmasterol, betulinic acid, linoleic acid, methyl-14-methylpentadecanoate, 13-epimanoyl oxide, and the depside atranorin (1), together with three aliphatic acids (hexadecanoic, tetraeicosanoic, hexaeicosanoic acids) and the two new triglycerides dihexadecanoyl-cis,cis8,11-eicosadienoyl glycerol (2) and dihexadecanoylcis,cis-6,9-octadecadienoyl glycerol (3).

\section{Results and Discussion}

The known natural compounds and the aliphatic acids were identified mainly by their ${ }^{1} \mathrm{H}$ and ${ }^{13} \mathrm{C}$ NMR and mass spectrometry analysis, including comparison with literature data (see experimental).

The depside atranorin (1) was identified by analysis of ${ }^{1} \mathrm{H}$ and ${ }^{13} \mathrm{C}$ NMR (HBBD and DEPT) including homonuclear $\left({ }^{1} \mathrm{H}-1 \mathrm{H}-\mathrm{COSY},{ }^{1} \mathrm{H}-{ }^{1} \mathrm{H}-\mathrm{NOESY}\right)$ and heteronuclear [1 ${ }^{1} \mathrm{H}-{ }^{13} \mathrm{C}-\mathrm{HMQC}-{ }^{1} \mathrm{~J}_{\mathrm{CH}},{ }^{1} \mathrm{H}-{ }^{13} \mathrm{C}-\mathrm{HMBC}-\mathrm{nJ}_{\mathrm{CH}}(\mathrm{n}=2$ and 3$)$ ] 2D NMR experiments, mass spectra and comparison with the ${ }^{1} \mathrm{H}$ NMR data of literature ${ }^{9}$. These data enabled us to assign unambigously the ${ }^{13} \mathrm{C}$ NMR chemical shifts of atranorin unreported in the literature. This depside has previously been isolated from lichens $9-11$ and it probably was found in the branches of L. nobilis because of a lichen symbiont growing on them.

Glycerides $\mathbf{2}$ and $\mathbf{3}$ were isolated together as a viscous oil which showed IR absorptions at 2919, 2848 and 726 $\mathrm{cm}^{-1}$ (alkyl chain), $1655 \mathrm{~cm}^{-1}$ (double bond) and $1737 \mathrm{~cm}^{-}$ 1 (ester carbonyl). The $1 \mathrm{H}$ and $13 \mathrm{C}$ NMR spectra (1D and $2 \mathrm{D}$ experiments) exhibited signals for olefinic hydrogen at $\delta 5.33(\mathrm{~m})$ connected to carbons at $\delta 129.9$ and 127.9. These signals, together with the absence of absorption around 


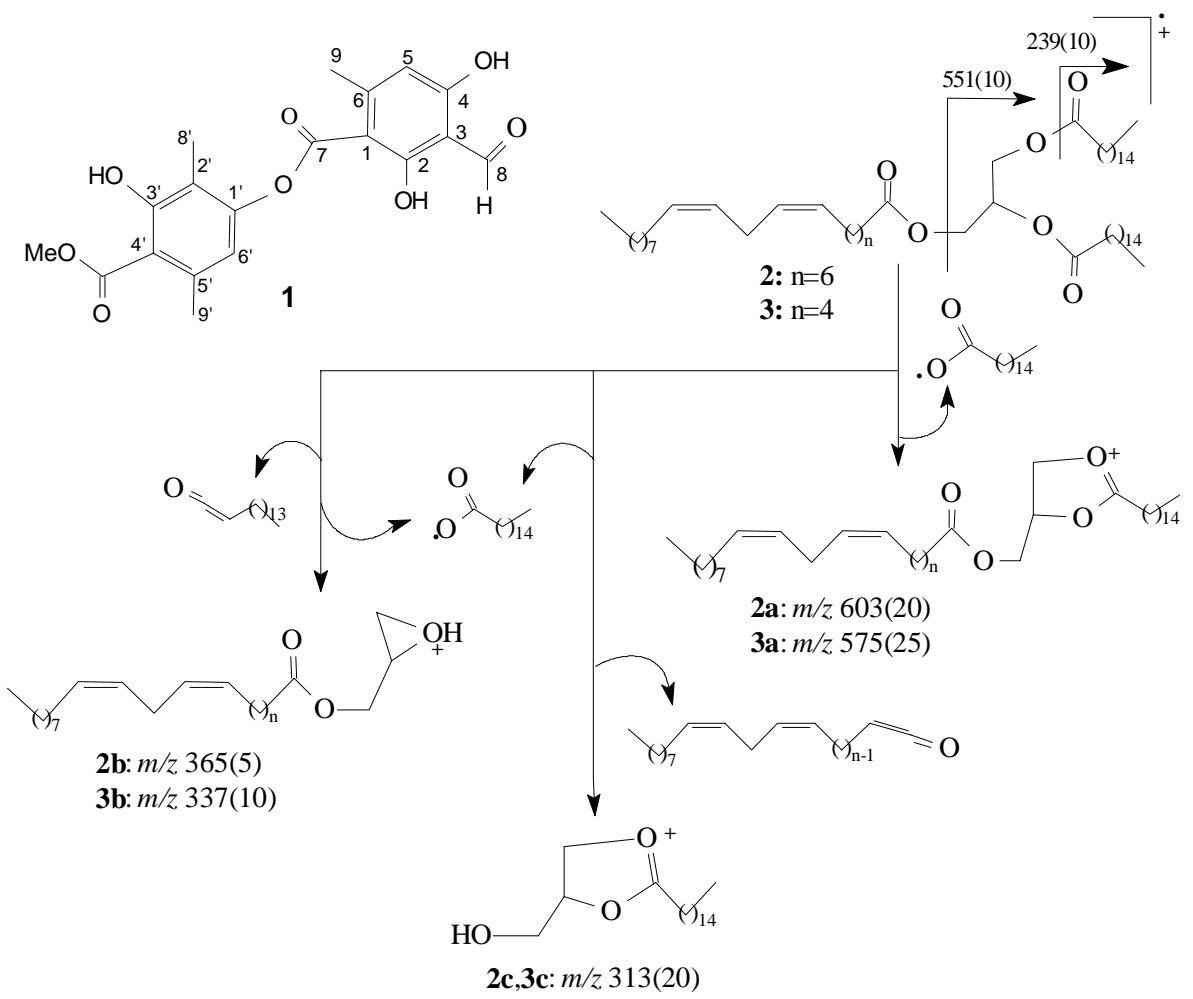

Scheme 1. Proposed fragmentation patterns of $\mathbf{2}$ and $\mathbf{3}$.

$970 \mathrm{~cm}^{-1}$ in the IR spectrum, indicate a cis geometry of the olefinic bonds. The coupling exhibited in the COSY spectrum between a hydrogen at $\delta 2.03(\mathrm{dd}, 14.0$ and $6.0 \mathrm{~Hz})$ and $\delta 2.78(\mathrm{~m})$ and the olefinic hydrogen indicates that the $\mathrm{CH}_{2}$ is connected to a double bond carbon. The connection of $\mathrm{CH}_{2}$ at $\delta_{\mathrm{H}} 2.03$ with $\delta_{\mathrm{C}} 27.2$ and at $\delta_{\mathrm{H}} 2,78$ with $\delta_{\mathrm{C}}$ $25.5\left(1 \mathrm{~J}_{\mathrm{CH}}\right)$ and 129.9 and $127.9\left(2,3 \mathrm{~J}_{\mathrm{CH}}\right)$ revealed in the HMQC and HMBC spectra, respectively, led us to propose the methylene interrupted diene for the unsaturated fatty esters (2 and 3). The comparison of the NMR data with those of methyl linoleate ${ }^{12}$ was used to confirm the nature of this unit in the glycerides. The other signals at $\delta_{\mathrm{H}} 5.25$ (m), 4.25 (dd,12.0, 5.0Hz), 4.15 (dd, 12.0,6.0Hz), 2.3 (t, $8.0 \mathrm{~Hz}), 1.68(\mathrm{~m}), 1.25(\mathrm{~m}), 0.87(\mathrm{t}, 8.0 \mathrm{~Hz})$ belong to hydrogens which connected, respectively, with carbons at $\delta_{\mathrm{C}}$ $68.9(\mathrm{CH}), 62.1\left(\mathrm{CH}_{2}\right), 62.1\left(\mathrm{CH}_{2}\right), 34.2\left(\mathrm{CH}_{2}\right), 24.8\left(\mathrm{CH}_{2}\right)$, 31.9-29.0 $\left(\mathrm{CH}_{2}\right)$ and $14.1\left(\mathrm{CH}_{3}\right)$ are in agreement with a triglyceryl ester. The FAB-mass spectra of the natural substances showed peaks at $\mathrm{m} / \mathrm{z} 603$ (2a), 575 (3a), 551 (from 2 and 3), 337 (2b), 313 (2c e 3c), 309 (3b) and 239 (from 2 and 3) which are in agreement with trigliceryl esters (Scheme 1). The possibility of an octadecanoic unit was also ruled out by the absence of a peak at $m / z 267$ in the mass spectrum. To locate the double-bond in the fatty acyl chain we used a procedure involving addition of dimethyl disulfide to the double bond followed by mass spectrometry analysis 13,14 .
The thiomethyl derivatives (4 and 5) showed an intense peak at $\mathrm{m} / \mathrm{z} 173$ (32\%, indicated in the structures $\mathbf{4}$ and $\mathbf{5}$ ) together with other peaks at the low mass end of the spectrum $(111,97,83,69,55$ and $41 \mathrm{u})$ which represent fragments of the terminal alkene, presumably due to the loss of $62\left(\mathrm{H}_{3} \mathrm{C}-\mathrm{S}-\mathrm{CH}_{3}\right)$ from $\mathrm{m} / z, 17313$. The analysis of mass spectra to justify the other peaks allowed proposition of the fragments indicated for 4 and $\mathbf{5}(\mathrm{m} / \mathrm{z}$ 551, 497, 469, 239) and the structures $\mathbf{4 a - 4 h}$ for $\mathbf{4}$ and $\mathbf{5 a}-\mathbf{5 h}$ for $\mathbf{5}$ (Scheme 2) which are in agreement with the double bonds at $\delta 8,11$ (2) and $6,9(3)$ in the olefinic acids. The same pattern of fragmentation was observed in the mass spectrum of the thiomethyl derivative of linoleic acid. These data and the $[\alpha]^{20} \mathrm{D}:+0.8$ (c $2.5, \mathrm{CDCl}_{3}$ ) were used to propose the structure of the new triglyceryl esters as dihexadecanoylcis, cis-8,11-eicosadienoyl glycerol (2) and dihexadecanoylcis,cis-6,9-octadecadienoyl glycerol (3).

\section{Experimental}

\section{General experimental procedures}

Melting points (m.p.) are uncorrected. Optical rotation was measured on a Perkin-Elmer 341. The ${ }^{1} \mathrm{H}$ and ${ }^{13} \mathrm{C}$ NMR spectra were recorded on a Varian Unity 400 spectrometer at 400 and $100 \mathrm{MHz}$, respectively. ${ }^{1} \mathrm{H}-{ }^{1} \mathrm{H}-\mathrm{COSY}$, 


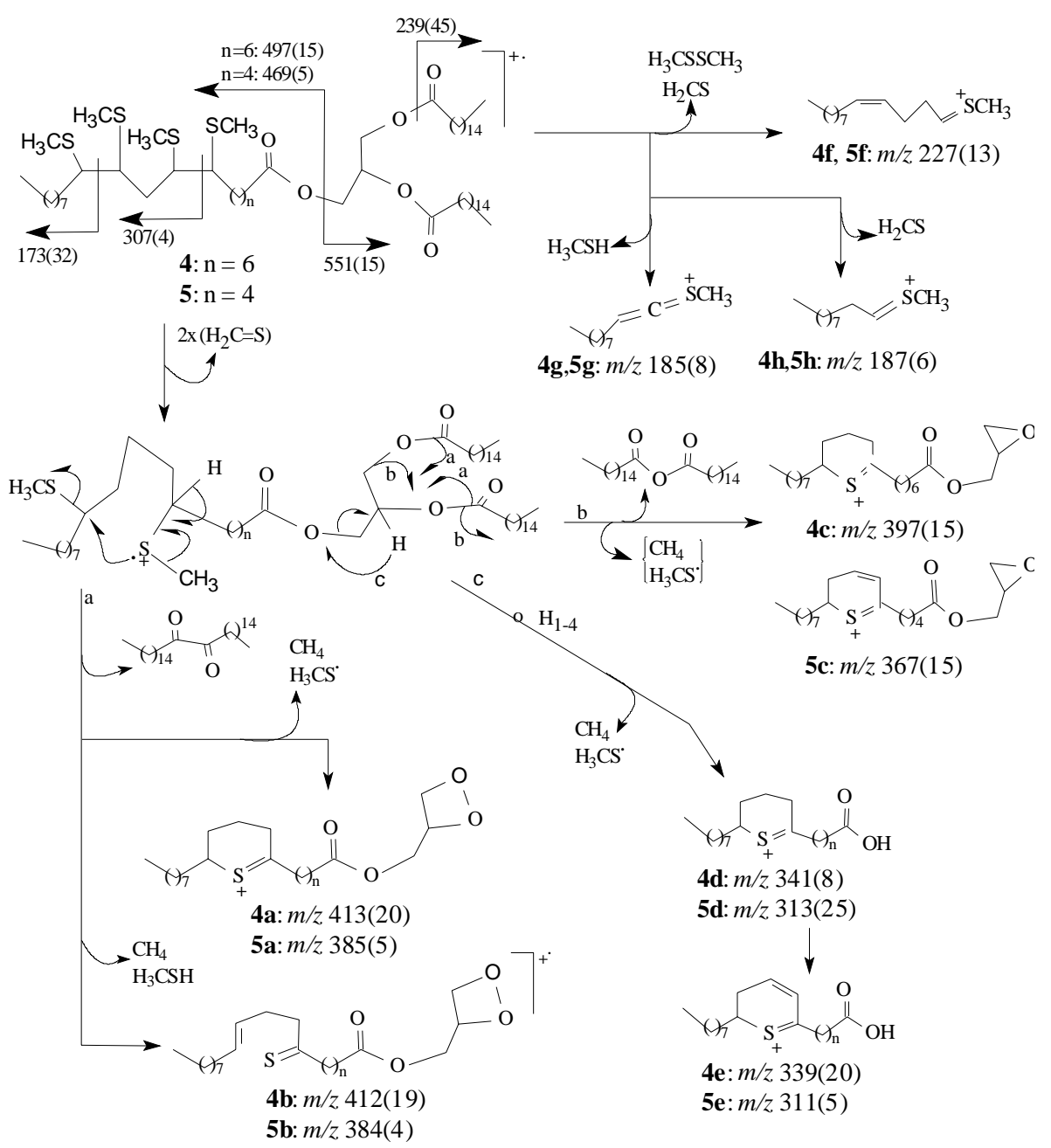

Scheme 2. Proposed fragmentation pathways of 4 and 5 (\%).

${ }^{1} \mathrm{H}-13 \mathrm{C}-\mathrm{COSY}$ (HMQC and HMBC) NMR experiments were performed on the same spectrometer, using standard Varian pulse sequences; HMBC and HMQC experiments were optimized for ${ }^{\mathrm{n}} \mathrm{CH}_{\mathrm{CH}}=9 \mathrm{~Hz}$ and ${ }^{1} \mathrm{~J}_{\mathrm{CH}}=140 \mathrm{~Hz}$. Mass spectra were determined with a VG Quattro instrument. The GC-MS analyses were determined with a VG Quatro-GC-8000, with triple quadrupole using gas flow $15 \mathrm{~mL} \mathrm{~min}^{-1}$ (12 $\left.\mathrm{psi} \mathrm{He}\right)$, source temp. $200^{\circ} \mathrm{C}$, pressure $1.10^{-4} \mathrm{mbar}$, colum HP5 (30 $\mathrm{m}$ x $0,32 \mathrm{~mm}$ ), temp. var. $150-300\left(10^{\circ} \mathrm{min}^{-1}\right)$, and $\mathrm{CH}_{2} \mathrm{Cl}_{2}$ was used as solvent. FT-IR spectra were recorded as a film on a PerkinElmer 1500 spectrometer. Chromatography was performed using silica gel (Merck) for column and preparative TLC. The purity of the compounds was checked by ${ }^{1} \mathrm{H}$ and ${ }^{13} \mathrm{C}$ NMR spectral analysis and TLC plate, revealed with UV $(254 \mathrm{~nm})$ and vanillin $(0.5 \mathrm{~g})$ in $\mathrm{H}_{2} \mathrm{SO}_{4}+\mathrm{EtOH}(40: 10)$.

\section{Plant material}

Luxemburgia nobilis samples were collected in Morro de São Sebastião, Ouro Preto, Minas Gerais, Brazil by Jorge
L. Silva who performed the identification by comparing it with a herbarium specimen (\# 6737) kept at the Herbarium José Badini of the Instituto de Ciências Exatas e Biológicas, Universidade Federal de Ouro Preto-M.G., Brazil.

\section{Extraction and isolation of the constituents}

Dried plant material (branches, $184 \mathrm{~g}$ ) was powdered and extracted with hexane by maceration at room temperature and the solvent was removed under vacuum to yield $3.85 \mathrm{~g}$ of residue. This residue was fractionated by solvent partition between hexane and methanol/ $\mathrm{H}_{2} \mathrm{O}(9: 1)$. The residue of the hexane part $(3.58 \mathrm{~g})$ was subjected to column chromatography on silica gel using hexane $/ \mathrm{CHCl}_{3}$ $(1: 1)$ increasing the polarity to methanol $(100 \%)$, collecting $20 \mathrm{~mL}$ fractions. Fractions 6-7 (15 mg) were analyzed by GC-MS and by comparison with a mass spectra library. This allowed the identification of methyl 14-methylpentadecanoate, linoleic acid and manoyl oxide $(56.6 \%$, $10.7 \%, 32.7 \%$, respectively). The presence of these 
compounds was confirmed by analysis of ${ }^{1} \mathrm{H}$ and ${ }^{13} \mathrm{C}$ NMR spectral data and comparison with those in the literature $12,15,16$. Fractions $10-11$ (173 mg, m.p. $68^{\circ} \mathrm{C}$ ) gave hexadecanoic acid, identified by analysis of its ${ }^{1} \mathrm{H}$ and ${ }^{13} \mathrm{C}$ NMR spectra and by observation of its molecular ion at $m / z 256$ (CI and FAB-MS). Fractions 12-15 afforded a mixture that was further purified by crystallization from hexane/EtOAc $(1: 1)$ to yield a mixture of triglycerides $(2$ +3, oil, $20 \mathrm{mg}$ ) and pure atranorin (1, $11 \mathrm{mg}$, m.p. 192 oC) 10,11. Fractions 17-19 (100 mg, m.p. 72 'C) yielded a mixture of tetraeicosanoic acid and hexaeicosanoic acid that were identified by ${ }^{1} \mathrm{H},{ }^{13} \mathrm{C}$ NMR and mass spectrometry (FAB and CI-MS) analysis. Fractions 36-51 (91 mg, m.p. $\left.115{ }^{\circ} \mathrm{C}\right)$ were found to contain two components, sitosterol and stigmasterol12,15. Fractions 54-60 were further purified by column chromatography using silica gel and elution with $\mathrm{CH}_{2} \mathrm{Cl}_{2} / \mathrm{MeOH}$ (9:1). Fractions $11-14$ of this second purification gave betulinic acid (30 mg, m.p. 295 oC), identified by comparison of ${ }^{1} \mathrm{H}$ and ${ }^{13} \mathrm{C}$ NMR data with those in the literature $12,17,18$. The residue of the methanol fraction (288 $\mathrm{mg}$ ) from the original solvent partition was subjected to column chromatography using silica gel and $\mathrm{CH}_{2} \mathrm{Cl}_{2}$ - methanol $(9: 1)$. Fractions $5-8(50 \mathrm{mg})$ were purified by preparative TLC to give betulinic acid and other compounds which could not be identified due to the limited amount of material.

Atranorin (1): Colorless crystal from hexane, m.p. 191$192 \mathrm{C}$; IR (KBr, cm$\left.{ }^{-1}\right)$ : 3450, 1660, 1580, 1450, 1400, 1280, 1260, 1166; ${ }^{1} \mathrm{H}$ NMR (400 MHz, $\left.\mathrm{CDCl}_{3}\right): 12.54$ (s, HO-4), 12.49 (s, HO-2), 11.94 (s, HO-3'),10.30 (s, H-8), 6.50 (s, H-6'), 6.39 (s, H-5), 3.97 (s, $\mathrm{H}_{3} \mathrm{CO}-7$ '), 2.67 (s, 3H-9), 2.53(s, 3H-9'), 2.07(s, 3H-8'). ${ }^{13} \mathrm{C} \mathrm{NMR}\left(100 \mathrm{MHz}, \mathrm{CDCl}_{3}\right)$ 193.8 (C-8), 172.2 (C-7'), 169.7 (C-7), 169.1 (C-2), 167.5 (C-4), 162.8 (C-3'), 152.4 (C-6), 152.0 (C-1'), 139.9 (C5'), 116.7 (C-2'), 115.9 (C-6'), 112.8 (C-5), 110,3 (C-4'), 108,5 (C-3), 102.8 (C-1), 52.3 ( $\mathrm{H}_{3} \mathrm{C}-\mathrm{O}-7$ '), 25.6 (C-9), 24.9 (C-9'), 9.4 (C-8');

Dihexadecanoyl-cis,cis-8,11-eicosadienoyl glycerol (2) + dihexadecanoyl -cis,cis-6,9-octadecadienoyl glycerol (3), oil, IR ( $\left.\mathrm{NaCl}, \mathrm{cm}^{-1}\right)$ : 2919, 1848, 1737, 1655, 726; ${ }^{1} \mathrm{H} \mathrm{NMR}\left(400 \mathrm{MHz}, \mathrm{CDCl}_{3}\right): 5.34$ [m, H-8,11 (2) and H-6,9 (3) ], 5.25 (m, H-2), 4.29 (dd, 12.0 and 5.0 Hz, H-1a, 3b), 4.15 (dd, 12.0 and $6.0 \mathrm{~Hz}, \mathrm{H}-1 \mathrm{~b}, 3 \mathrm{a}), 2.78$ (dd, 14.0 and $\left.6.0 \mathrm{~Hz},=\mathrm{CH}-\underline{\mathrm{H}}_{2} \mathrm{C}-\mathrm{CH}=\right), 2.30$ (t, $\left.7.0 \mathrm{~Hz}, \mathrm{H}_{2} \mathrm{C}-\mathrm{CO}\right), 2.03$ (m, $\left.\mathrm{H}_{2} \mathrm{C}-\mathrm{C}=\right) 1.60\left(\mathrm{~m}, \underline{\mathrm{H}}_{2} \mathrm{C}-\mathrm{CH}_{2}-\mathrm{C}=\right), 1.25\left[\mathrm{~m},\left(\mathrm{CH}_{2}\right)_{\mathrm{n}}\right], 0.87(\mathrm{t}$, 7.0Hz, $\left.\mathrm{CH}_{3}\right)$; ${ }^{13} \mathrm{C} \mathrm{NMR}\left(100 \mathrm{MHz}, \mathrm{CDCl}_{3}\right): 173.3(\mathrm{C}=\mathrm{O})$, $173.2(\mathrm{C}=\mathrm{O} \times 2), 129.9,127.9(\mathrm{HC}=\underline{\mathrm{CH}}), 68.9(\underline{\mathrm{CHO}}), 62.1$ $\left(\mathrm{CH}_{2}-\mathrm{O} \times 2\right), 34.2\left(\mathrm{CH}_{2}-\mathrm{CO}\right), 31.9\left(\mathrm{CH}_{2}\right), 29.7-29.0\left(\mathrm{CH}_{2}\right)$, $27.2\left(\underline{\mathrm{CH}}_{2}-\mathrm{C}=\right), 25.5\left(=\mathrm{C}-\underline{\mathrm{CH}}_{2}-\mathrm{C}=\right), 24.8\left(\mathrm{CH}_{2}-\mathrm{C}=\mathrm{O}\right), 14.1$ $\left(\mathrm{CH}_{3}\right)$; FAB-MS (Glycerol matrix, positive ion mode) $\mathrm{m} / \mathrm{z}$ (rel. int.): 603 (2a, 20\%), 575 (3a, 25\%), 551 (10), 337 (2b,10), 313 (2c, 3c, 20), 309 (3b, 5), 239 (10).
Preparation of thiomethyl ethers $(4+5)$.

Dimethyl disulfide $(2.0 \mathrm{~mL})$ and the triglyceride (5.0 $\mathrm{mg}$ ) were placed in a vial with a septum equipped with a magnetic stirrer and $0.5 \mathrm{~mL}$ of a clear solution of $\mathrm{I}_{2}$ in MeSSMe (3 mL) was added to the mixture. The flask was purged with argon using two needles. After stirring for 24 $\mathrm{h}$ at room temperature, the reaction was completed. The product was subjected directly to EI-MS and FAB-MS analysis (Scheme 2).

\section{Acknowledgements}

The authors are grateful to CNPq and CAPES for research fellowship and for support from Conselho Nacional de Desenvolvimento Científico e Tecnológico ( $\mathrm{CNPq}$ ), Financiadora de Estudos e Projetos (FINEP) and Fundação de Amparo a Pesquisa do Estado do Rio de Janiro (FAPERJ). We thank Dr. D. G. I. Kingston of Department of Chemistry, Virginia Polytechnic Institute and State University, Blacksburg, Virginia, 24061-0212, USA, for allowing the use of the laboratory during the visit of M. G. de C. and for the English review.

\section{References}

1. Mors, W. B.; Rizzini, C. T. Useful Plants of Brazil. Holden-Day, San Francisco, 1966.

2. Braga, R. Plantas do Nordeste, especialmente do Ceará (2nd Ed.), Imprensa Oficial, Fortaleza, Ceará, Brazil, 1960.

3. Moreira, I. C.; Sobrinho, D. C.; Carvalho, M. G. de, Braz-Filho, R. Phytochemistry 1994, 35, 1567.

4. Bastos, A. B. O.; Carvalho, M. G. de; Moreira, I. C.; Braz-Filho, R. Phytochemistry, 1999, 51, 833.

5. Velandia, J. R.; Carvalho, M. G. de; Braz-Filho, R. Nat. Prod. Lett., 1998, 12, 191.

6. Velandia, J. R.; Carvalho, M. G. de; Braz-Filho, R. Quím. Nova 1998, 21, 397.

7. Valandia, J. R. Constituintes Químicos de Ouratea semiserrata e Transformações Químicas da Neolignana Aureína CPGQO - Departamento de Química, Universidade Federal Rural do Rio de Janeiro, Seropédica, RJ, 1997.

8 (a) Grynberg, N. F.; Mortorelli, R. A.; Carvalho, M. G. de; Braz-Filho, R.; Moreira, I. C.; Santos, A. C. S.; Echevarria, A. Proceedings of the XVI International Cancer Congress, 1994, 63.

(b) Grynberg, N. F., Brioso, P. S. T., Velandia, J. R., Echevarria, A., Carvalho, M. G. de; Braz-Filho, R. Proceedings of the XVII International Cancer Congress, 1998, 317. 
9. Huneck, S.; Linscheid, P. Z. Naturforschg. 1968, $23 b, 717$.

10. Elix, J. A.; Mahadevan, I.; Wardlaw, J. M.; Awidson, L.; Jorgensen, P. M. Austr. J. Chem. 1987, 40, 1581.

11. Elix, J. A.; Barclay, C. E.; David, F.; Griffin, F. K.; Hill, A. M.; McConnel, D. B.; Wardlaw, J. H. Austr. J. Chem. 1993, 46, 301.

12. Pouchert, C. J.; Behnke, J. The Aldrich Library of ${ }^{13} \mathrm{C}_{\text {and }}{ }^{1} \mathrm{H}$ NMR Spectra, Ed.I, Vol. 1 and 2, 1993.

13. Gonzales, M. J. T. G.; Oliveira, C. J. C. de; Fernandes, J.
O.; Kijjoa, A.; Herz, W. Phytochemistry 1996, 46, 1333. 14. Francis, G. W.; Veland, K. J. Chromatogr. 1981, 219, 379.

15. Goulart, M. O. F.; Sant'Ana, A. E. G.; Lima, R. A. de; Cavalcante, S. H.; Carvalho, M.G. de; Braz-Filho, R. Quím. Nova 1993, 16, 95.

16. Pereira, O.L.; Filho, W.W.; Rocha, A.F.I. da; Carvalho, M.G. de; Braz-Filho, R. Quím. Nova 1990, 13, 247.

17. Mahato, S. B.; Kundu, A. P. Phytochemistry 1994, 37, 1517.

18. Seo, S.; Tomita, Y.; Tori, K. Tetrahedron Lett. 1975, $1,7$.

Received: June 24, 1999 